\title{
Correction to: Co-expression of SOX2 and HR-HPV RISH predicts poor prognosis in small cell neuroendocrine carcinoma of the uterine cervix
}

Shi-Wen Zhang ${ }^{1,2+}$, Rong-Zhen Luo ${ }^{1+}$, Xiao-Ying Sun ${ }^{3+}$, Xia Yang ${ }^{1}$, Hai-Xia Yang ${ }^{1}$, Si-Ping Xiong ${ }^{1}$ and Li-Li Liu ${ }^{1 *}$

\section{Correction to: BMC Cancer 21, 332 (2021) \\ https://doi.org/10.1186/s12885-021-08059-1}

Following publication of the original article [1], the authors reported an error in the order of the affiliations. The correct affiliations are reflected in this article. The original article [1] has been corrected.

\footnotetext{
Author details

'Department of Pathology, Sun Yat-sen University Cancer Center, Guangzhou 510060, China. ${ }^{2}$ Department of Pathology, the Eighth Affiliated Hospital, Sun Yat-sen University, Shenzhen 51800, China. ${ }^{3}$ Department of Gynecological Oncology, Sun Yat-sen University Cancer Center, Guangzhou 510060, China.
}

Published online: 15 April 2021

\section{Reference}

1. Zhang SW, Luo RZ, Sun XY, Yang X, Yang HX, Xiong SP, et al. Co-expression of SOX2 and HR-HPV RISH predicts poor prognosis in small cell neuroendocrine carcinoma of the uterine cervix. BMC Cancer. 2021;21(1): 332. https://doi.org/10.1186/s12885-021-08059-1.

The original article can be found online at https://doi.org/10.1186/s12885021-08059-1.

* Correspondence: liulil@sysucc.org.cn

†'Shi-Wen Zhang, Rong-Zhen Luo and Xiao-Ying Sun contributed equally to this work.

'Department of Pathology, Sun Yat-sen University Cancer Center, Guangzhou 510060, China

Full list of author information is available at the end of the article

(c) The Author(s). 2021 Open Access This article is licensed under a Creative Commons Attribution 4.0 International License, which permits use, sharing, adaptation, distribution and reproduction in any medium or format, as long as you give appropriate credit to the original author(s) and the source, provide a link to the Creative Commons licence, and indicate if changes were made. The images or other third party material in this article are included in the article's Creative Commons licence, unless indicated otherwise in a credit line to the material. If material is not included in the article's Creative Commons licence and your intended use is not permitted by statutory regulation or exceeds the permitted use, you will need to obtain permission directly from the copyright holder. To view a copy of this licence, visit http://creativecommons.org/licenses/by/4.0/ The Creative Commons Public Domain Dedication waiver (http://creativecommons.org/publicdomain/zero/1.0/) applies to the data made available in this article, unless otherwise stated in a credit line to the data. 